\title{
Evaluation of the psychiatry consultations of inpatients in Palliative Care Unit of Adiyaman Training and Research Hospital: 2018 data
}

\author{
Adıyaman Eğitim ve Araştırma Hastanesi Palyatif Bakım Ünitesinde yatarak tedavi gören \\ hastalara istenen psikiyatri konsültasyonlarının değerlendirilmesi: 2018 yılı verileri
}

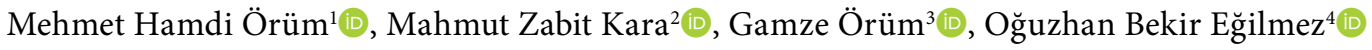 \\ Department of Psychiatry, Kahta State Hospital, Adiyaman, Turkey \\ Department of Child and Adolescent Psychiatry, University of Health Sciences, Antalya Training and Research Hospital, Antalya, Turkey \\ Undergraduate Student, Inönü University Faculty of Nursing, Malatya, Turkey \\ Department of Psychiatry, Adryaman University Faculty of Medicine, Adryaman, Turkey
}

\begin{abstract}
Objectives: This study aims to evaluate the psychiatric consultations requested in the inpatients of the palliative care unit.

Patients and methods: Data such as age, gender, main disease diagnosis, psychiatric diagnosis, and the date of consultation from the patient registry system in the Palliative Care Unit of Adıyaman Training and Research Hospital were retrospectively evaluated. In this study, 53 patients (26 males, 27 females; mean age $64.7 \pm 15.7$ years; range, 29 to 92 years) who were requested consultation between January 1, 2018 and December 31,2018 were evaluated.

Results: The mean age of men and women was similar $(p=0.272)$. The main diagnoses of the patients were: cancer-leukemia-lymphoma $(n=35,66.2 \%)$, infections ( $n=7,13.4 \%)$, cerebrovascular accident $(n=5,9.1 \%)$, diabetes mellitus $(n=4,7.6 \%)$, chronic obstructive pulmonary disease ( $n=2$, $3.8 \%)$. Decubitus ulcers were present in all of these patients. According to DSM-V criteria, the most frequent psychiatric diagnoses were as follows: major depressive disorder in 17 patients (32.1\%), sleep disorder in 17 patients (32.1\%), delirium 16 patients $(30.2 \%)$. The number of seasonal consultation requests were similar ( $p=0.345)$. Principal diagnoses were similar in both genders $(p=0.329)$. Psychiatric diagnoses were similarly distributed in both genders $(p=0.467)$. Major depressive disorder was significantly more frequent in younger patients compared to other psychiatric diagnostic groups ( $p=0.008$ ).

Conclusion: The most important psychiatric diagnoses of patients in palliative care units are delirium, sleep disorders, and major depressive disorder. Primary or secondary psychiatric disorders added to the burden of severe disease negatively affect patient compliance to treatment. For these reasons, it is recommended that patients are under close follow-up and treatment.

Keywords: Delirium, major depressive disorder, palliative care, psychiatric consultation.
\end{abstract}

ÖZ

Amaç: Bu çalışmada palyatif bakım ünitesinde yatarak tedavi gören hastalara istenen psikiyatri konsültasyonları değerlendirildi.

Hastalar ve yöntemler: Adıyaman Eğitim ve Araştırma Hastanesi Palyatif Bakım Ünitesi'nde yatarak tedavi gören hastaların yaş, cinsiyet, ana hastalık tanısı, psikiyatrik tanı, konsültasyon isteminin yapıldığı tarih gibi veriler hasta kayıt sisteminden geriye dönük olarak incelendi. Bu çalışmada, 1 Ocak 2018 ve 31 Aralık

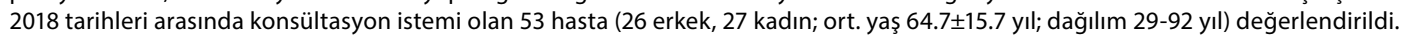

Bulgular: Erkek ve kadın yaş ortalamaları benzerdi $(p=0.272)$. Hastaların ana yatış tanıları şunlardı: kanser-lösemi-lenfoma $(n=35, \% 66.2)$, enfeksiyonlar ( $n=7$, \%13.4), serebrovasküler olay ( $n=5, \% 9.1)$, diabetes mellitus $(n=4, \% 7.6)$ ve kronik obstrüktif akciğer hastalığı ( $n=2, \% 3.8)$. Bu hastaların tamamında dekübitus ülseri mevcuttu. Hastalara DSM-5 tanı kriterlerine göre en sık konulan psikiyatrik tanılar şöyleydi: Majör depresif bozukluk 17 hasta (\%32.1), uyku bozukluğu 17 hasta (\%32.1), deliryum 16 hasta (\%30.2). Mevsimsel konsültasyon istem sayıları benzerdi $(p=0.345)$. Temel yatış tanıları her iki cinsiyette benzer idi ( $p=0.329)$. Psikiyatrik tanılar her iki cinsiyette de benzer idi $(p=0.467)$. Majör depresif bozukluk anlamlı olarak diğer psikiyatrik tanı gruplarından farklı olarak daha genç yaştaki hastalarda sıktı ( $\mathrm{p}=0.008)$.

Sonuç: Palyatif bakım ünitelerindeki hastaların en önemli psikiyatrik tanıları deliryum ve uyku bozuklukları ile birlikte majör depresif bozukluktur. Ağır hastalık yükü üzerine eklenen primer veya sekonder psikiyatrik bozukluklar hastaların tedaviye olan uyumunu kötü etkilemektedir. Bu nedenlerle hastaların ruhsal açıdan yakın takip ve tedavi altında olmaları önerilir.

Anahtar sözcükler: Deliryum, majör depresif bozukluk, palyatif bakım, psikiyatri konsültasyonu.

Received: May 19, 2019 Accepted: June 10, 2019 Published online: July 31, 2019

Correspondence: Mehmet Hamdi Örüm, MD. Kahta Devlet Hastanesi, Psikiyatri Polikliniği, 02100 Adıyaman, Turkey. Tel: +90 416 - 2161015 / 1186 e-mail: mhorum@hotmail.com 
According to the World Health Organization (WHO) definition, palliative care is a treatment system that improves the quality of life of patients and their families facing problems associated with life-threatening illness, through the prevention and relief of suffering by means of early identification, assessment, and treatment of pain and other physical and psychosocial problems. ${ }^{[1]}$ Pain is an unpleasant and distressing emotional experience. The individual's personality is threatened by illness. Illness deteriorates the person's concept of "self" and pain is a symptom of this degradation. ${ }^{[2]}$

Pain embodies the physical, psychological, spiritual, and philosophical aspects of the person. In medicine, there is no common tool to address all components of suffering caused by disease. The suffering of a cancer patient in pain may not be completely eliminated, but if adequate relief is provided, state of wellbeing may be elevated by strengthening tolerance mechanisms. ${ }^{[3]}$ Multidisciplinary intervention is required to overcome this difficulty. Modern medicine, which concentrates on cures instead of care, focuses on biology instead of psychology and sociology. The subdivision of medicine, which has become inevitable to large accumulation of clinical and scientific knowledge, has limited the possibilities of joint decision-making under various specialties and subspecialties. ${ }^{[4]}$

Psychiatry and palliative care are fields that address patients with mental distress and are living in their final stages of life. Both fields are less convenient than other medical fields for biomedical interventions. These fields, associated with art as much as science, are bio-psycho-social medical practice fields. ${ }^{[5]}$ The clinical outcome that is intended to be achieved by psychiatry is to alleviate mental stress and ensure a state of "well-being". In palliative medicine, this could be defined as "a good death". In both branches, the best thing to do is to provide symptom control and maintain continuity of this control. Therefore, quality of life is improved and pain decreases. With these thoughts, early studies in this field also predicted that palliative care would encompass the physical, psychological, and mental aspects of illness. It is known that symptoms of grief experienced on the deathbed are not only physical, but have prominent spiritual facets. Some events are evaluated foremost as psychologic or psychiatric, others psychosomatic or "somatopsychic". $[5,6]$

Patients living in their final stages develop various psychiatric disorders. A portion of these disorders can be pharmacologically treated, while others require a serious therapy process. More importantly, there is a need for approaches that address issues related to the existence of the patient and integrate pharmacological treatment and psychotherapy. ${ }^{[7]}$ However, as in many parts of the world, consultation liaison psychiatry (CLP) services are far below the demand. Palliative care nurses usually have significant experience and intuitional skills in dealing with distressed patients, however do not have a psychiatric knowledge base. It is possible to meet some of this need by developing the psychiatric skills of palliative caregivers and encouraging partnership. In this regard, during the foundation period of palliative care, the main in-service educational fields were on communication skills. In recent times, depression, the psycho-social aspects of pain, and delirium have been the main fields of educational efforts. ${ }^{[5,8]}$

Acquiring the patient's story is the basic clinical ability of medicine. The patient is the one in pain and knows his/her symptoms, while the doctor's role is to acquire and expertly interpret this information. The patient's story provides information on which diagnostic hypotheses have previously been formulated. Definite diagnosis is determined based on differential diagnoses with the help of clinical examination and objective information provided by research. ${ }^{[9]}$ Psychiatric story is a bit different than other medical stories. The patient's explanation of symptoms and giving them the chance to explain their narrative is the key to acquiring the patient's story. In this regard, questions of "how" play an important role. Open-ended questions such as "How does your health affect you?" and "How do you feel?" are commonly asked. Subjects of hallucinations and suicidal thoughts should be especially questioned in end-stage patients. Delirium, depression, anxiety, and cognitive function disorders are common mental health problems in end-stage patients. In this period, time is limited because energy and cooperation skills are threatened. ${ }^{[7,10]}$

Clinical psychiatry and medical practice generally require knowledge of psychology, 
personality traits, coping abilities, general intellectual functions, and present stressors that affect adaptation to illness and ability to live with illness. ${ }^{[9,11]}$ Urgent intervention of disease burden and psychiatric disorders at various levels according to the patient's characteristics is an important part of palliative care. ${ }^{[5]}$ Psychiatry discipline includes both organic and psychological dysfunction. Evaluation of the CLP services of a hospital facilitates plans for the future. The main themes of necessary in-service education could be determined. ${ }^{[12]}$ In this study, we aimed to evaluate the psychiatric consultations of inpatients hospitalized in the palliative care unit of the Adyyaman Training and Research Hospital.

\section{PATIENTS AND METHODS}

Our study was planned to have a retrospective design. Psychiatric consultations of palliative care inpatients from between January 1, 2018 and December 31, 2018 were taken under evaluation. Information was obtained from the hospital database. Consultation requests of our hospital are made via the internet and consultation responses are also realized over the database. Between the designated dates, psychiatry consultations of 53 patients (26 males, 27 females; mean age $64.7 \pm 15.7$ years; range 29 to 29 years) were accessed. Complete data such as age, gender, consultation date, main diagnosis for hospitalization, and psychiatric diagnosis of the patients were transferred to a setting for statistical analysis.

Diagnostic and Statistical Manual of Mental Disorders Fifth Edition (DSMV) was used for classification of psychiatric diagnosis. ${ }^{[13]}$ Psychiatric diagnoses mentioned in the study were as follows: anxiety disorder, major depression disorder, delirium, acute stress response, and sleep disorder; primary diagnoses included: cancer-leukemia-lymphoma, cerebrovascular accident, infections, chronic obstructive pulmonary disease, and diabetes mellitus. This study received ethics approval from the Adiyaman University Faculty of Medicine Non-Interventional Clinical Research Ethics Committee Department (2019/3-4). The study was conducted in accordance with the principles of the Declaration of Helsinki.

\section{Statistical analysis}

The IBM SPSS version 22.0 (IBM Corp., Armonk, NY, USA) statistical program was used for statistical analysis. Descriptive statistics and continuous variables were expressed as mean \pm standard deviation, while categorical variables were expressed as frequency and percentage. Chisquare test was used for comparisons. The value of $p<0.05$ was considered statistically significant for all values.

\section{RESULTS}

The mean age of female patients was $67.0 \pm 15.4$ years, and mean age of male patients was $62.3 \pm 15.9$ years. Mean female and male age were similar $(p=0.272)$. Consultations took place in the palliative care service in 48 patients (90.6\%) and in the psychiatry clinic in five (9.4\%).

Principal diagnosis was as follows: cancerleukemia-lymphoma ( $\mathrm{n}=35,66.2 \%)$, infections $(n=7,13.4 \%)$, cerebrovascular accident $(n=5,9.1 \%)$, diabetes mellitus ( $\mathrm{n}=4,7.6 \%)$, chronic obstructive pulmonary disease $(n=2,3.8 \%)$. Decubitus ulcer was present in all of these patients.

Psychiatric diagnoses according to DSM-V diagnostic criteria were as follows: major depressive disorder $(n=17,32.1 \%)$, sleep disorder $(n=17$, $32.1 \%)$, delirium $(n=16,30.2 \%)$, anxiety disorder $(\mathrm{n}=2,3.8 \%)$, acute stress response $(\mathrm{n}=1,1.9 \%)$.

Number of seasonal consultation requests were similar $(\mathrm{p}=0.345)$. Mean age was $60.0 \pm 2.8$ years in patients with anxiety disorder, $56.8 \pm 12.7$ years in major depressive disorder, $72.0 \pm 15.9$ years in delirium, 29.0 years in acute stress response, and $68.4 \pm 13.5$ years in sleep disorder patients. Principal diagnoses were similar in both genders $(p=0.329)$. Psychiatric diagnoses were similar in both genders $(p=0.467)$. There was no difference between genders according to examinations performed in place and in the clinic $(p=0.329)$. Major depressive disorder was significantly higher in younger patients compared to other psychiatric diagnosis groups $(p=0.008)$.

\section{DISCUSSION}

According to the results of this study, the most important psychiatric diagnoses to be emphasized in patients in palliative care units are 
delirium, sleep disorders, and major depressive disorder. Major depressive disorder carries a more prominent burden in patients of a younger age. A large majority of patients in palliative care units are cancer patients.

Primary and secondary psychiatric disorders added to the burden of fatal disease negatively affects patient compliance to treatment. Burden of psychiatric disease is heavier in cancer patients; $20-30 \%$ of cancer patients have a psychiatric disorder diagnosis, in which major depressive disorder is the most common. ${ }^{[14]}$ Furthermore, there is a relatively high number of patients with undiagnosed depressive symptoms severe enough to negatively impact functionality. Reluctance, psychomotor retardation, agitation, concern, inability to concentrate, thoughts of death, fatigue, weight loss, or other complaints that can accompany depressive symptoms. ${ }^{[7,14]}$ Tokgoz et al. ${ }^{[15]}$ reported that depression prevalence was $22 \%$ among cancer patients. Wilson et al. ${ }^{[16]}$ conducted a study on cancer patients undergoing palliative care and reported that $24.4 \%$ of patients were diagnosed with either major depressive disorder or anxiety disorder, that $10.2 \%$ were diagnosed with more than one psychiatric disorder, and that younger patients faced heavier burden of depressive disorder $(p=0.002)$. In our study, a large portion of the patients met diagnostic criteria for major depressive disorder and depressive disorder burden significantly increased as age decreased. It is believed that a combination of psychotherapy applications and pharmacological treatment could reduce psychiatric illness burden to a tolerable level. Sleep disorder is common among patients diagnosed with depression. ${ }^{[17-20]}$

Sleep disorders are present in almost all palliative care patients, and are especially frequent in cancer patients. Sleep disorder may develop as a primary or sometimes secondary disorder. It may develop sometimes due to depressive symptoms, sometimes worry, sometimes pain due to physical illness, and sometimes drugs. Despite all this, sleep disorder is a neglected issue. One reason for this is because this condition is viewed as a normal or temporary reaction to cancer diagnosis or treatment, the other is that patients do not report their sleep disorders. Sleeplessness in cancer patients is frequently severe enough to require medical attention. Prevalence of sleep disorder is $50 \%$ in cancer patients, and relatively higher in females compared to males, and more common in breast cancer patients. Studies on cancer patients and cancer-survivors have shown that fatigue is associated with sleep parameters including poor sleep quality, difficulty falling and staying asleep, perception of insufficient sleep, non-refreshing and restless sleep. For this reason, treatment of one symptom may also affect the other. Underlying common etiology of cancerrelated fatigue and sleep disorders has also been associated with pain, depression, and lack of concentration and cognitive functions in both conditions. ${ }^{[21,22]}$ It was observed in our study that the level of sleep disorder diagnoses was not to be underestimated. Another psychiatric condition encountered in cognitive disorders is delirium. ${ }^{[23,24]}$

Prevalence of delirium, a clinical syndrome characterized by sudden-onset dysfunction of attention and cognitive function, is $11-16 \%$ among inpatients hospitalized due to physical illness with a more widespread distribution between 4-31\%.[25] According to a systematic review of eight studies by Hosie et al., ${ }^{[26]} 98.9 \%$ of inpatients receiving palliative care were cancer patients, delirium incidence was 3-35\%, and delirium prevalence ranged between 13.3-42.3\% at hospital admission. In our study, delirium was also reported to be frequent among palliative care services.

There is increasing need for psychiatrists to work with patients and their families facing chronic, life-threatening diseases. In addition, psychiatrists may greatly contribute to the field of palliative care related to prevention and reduction of all forms of pain. With the development of medical treatment methods, individuals may live increasingly longer with many problems that may lead to bio-psycho-social sequelae. In order to ensure the most modern and appropriate care for patients and families during the period of diagnosis and treatment, there is a need for many psychiatrists, interdisciplinary palliative care teams, and consultants experienced in this field. ${ }^{[5,27]}$

In conclusion, this study is important in terms of supporting studies showing that the most common primary diagnoses in palliative care units are cancer and related conditions, the most common psychiatric diagnoses are major depressive disorder, sleep disorder, and delirium, and that 
depressive symptoms increase as age decreases. Psychiatry practices in which a combination of drug treatments and psychotherapy is used will prevent poor compliance to treatment by patients with primary and secondary psychiatric disorders added to illness requiring palliative care. It is recommended that patients receiving palliative care treatment should be closely followed and treated in terms of mental health.

\section{Declaration of conflicting interests}

The authors declared no conflicts of interest with respect to the authorship and/or publication of this article.

\section{Funding}

The authors received no financial support for the research and/or authorship of this article.

\section{REFERENCES}

1. Available at: https://www.who.int/cancer/palliative/ definition/en/

2. Finkelstein-Fox L, Park CL. Control-coping goodnessof-fit and chronic illness: a systematic review of the literature. Health Psychol Rev 2019;13:137-62.

3. Ingersoll LT, Alexander SC, Priest J, Ladwig $\mathrm{S}$, Anderson W, Fiscella K, et al. Racial/ethnic differences in prognosis communication during initial inpatient palliative care consultations among people with advanced cancer. Patient Educ Couns 2019;102:1098-103.

4. Kozlov E, Niknejad B, Reid MC. Palliative care gaps in providing psychological treatment: a review of the current state of research in multidisciplinary palliative care. Am J Hosp Palliat Care 2018;35:505-10.

5. Trachsel M, Irwin SA, Biller-Andorno N, Hoff P, Riese F. Palliative psychiatry for severe persistent mental illness as a new approach to psychiatry? Definition, scope, benefits, and risks. BMC Psychiatry 2016;16:260.

6. Sexton JM, Zeris S, Davies PS, Loggers ET, Fann JR. Palliative care training for psychiatry residents: development of a pilot curriculum. Acad Psychiatry 2016;40:369-71.

7. Weil AR. Advanced illness and end-of-life care. Health Aff (Millwood) 2017;36:1167.

8. Fairman N, Irwin SA. Palliative care psychiatry: update on an emerging dimension of psychiatric practice. Curr Psychiatry Rep 2013;15:374.

9. Nierenberg R. The chief complaint driven medical history: implications for medical education. Int $\mathrm{J}$ Med Educ 2017;8:205-6.

10. Regard L. Psychiatry and palliative care, collaboration for the benefit of the patient. Rev Infirm 2018;67:367. [Abstract]
11. Ozen ME, Orum MH, Kalenderoglu A. Difficult patient in psychiatry practice: A case-control study. Adiyaman Üni Sağlık Bilimleri Derg 2018;4:1064-73.

12. Grover S, Avasthi A. Consultation-liaison psychiatry in India: Where to go from here? Indian J Psychiatry 2019;61:117-24.

13. Diagnostic and statistical manual of mental disorders. 5th ed. Washington: American Psychiatric Association; 2013.

14. Güleç G, Büyükkınacı A. Kanser ve psikiyatrik bozukluklar. Psikiyatride Güncel Yaklaşımlar 2011;3:343-67.

15. Tokgöz G, Yaluğ İ, Özdemir S, Yazıcı A, Uygun K, Aker T. Kanser hastalarında major depresyon yaygınlığı ve ilişkili etsenler. Anadolu Psikiyatri Dergisi 2008;9:59-66.

16. Wilson KG, Chochinov HM, Skirko MG, Allard P, Chary S, Gagnon PR, et al. Depression and anxiety disorders in palliative cancer care. J Pain Symptom Manage 2007;33:118-29.

17. Özen ME, Örüm MH, Öner RI, Kalenderoğlu A, Atmaca M. Hipotiroidizmin levotiroksin ile tedavisine rağmen devam eden uyku bozukluğu depresyon için bir belirteç olabilir mi? Adıyaman UUniversitesi Sağlık Bilimleri Dergisi 2018;4:1019-27.

18. Ozen ME, Orum MH, Kalenderoglu A, Atmaca M. Improvement of an atypical Kikuchi-Fujimoto Disease (KFD) with antidepressant treatment: The first psychiatric approach to a KFD case. Psychiatry Clin Psychopharmacol 2019;29:107-9.

19. Orum MH, Kalenderoglu A. The treatment process of a patient with postpartum depression who conceived with in vitro fertilization technique: A case report. FNG \& Demiroğlu Bilim Tip Dergisi 2017;3:120-4.

20. Sterpenich V, Vidal S, Hofmeister J, Michalopoulos G, Bancila V, Warrot D, et al. Increased reactivity of the mesolimbic reward system after ketamine injection in patients with treatment-resistant major depressive disorder. Anesthesiology 2019;130:923-35.

21. Bernatchez MS, Savard J, Savard MH, Aubin M, Ivers $\mathrm{H}$. Sleep-wake difficulties in community-dwelling cancer patients receiving palliative care: subjective and objective assessment. Palliat Support Care 2018;16:756-66.

22. Özen ME, Örüm MH, Kalenderoğlu A, Karaçor T, Bucak $\dot{\mathrm{I}} \mathrm{H}$, Atmaca M. Lohusalı dönemindeki kadınlarda uyku kalitesi ve gündüz aşırı uykululuk halinin incelenmesi. FNG \& Demiroğlu Bilim Tip Dergisi 2018;4:111-4.

23. Cirbus J, MacLullich AMJ, Noel C, Ely EW, Chandrasekhar R, Han JH. Delirium etiology subtypes and their effect on six-month function and cognition in older emergency department patients. Int Psychogeriatr 2019;31:267-76.

24. Örüm MH, Kara MZ, Kuştepe A, Kalenderoğlu A. Bilişsel hatalar ve dikkat-eksikliği hiperaktivite bozukluğu belirtilerinin madde kullanım özellikleri ile ilişkisi. Bağımlllık Dergisi 2019;20:47-60. 
25. OnurE, CimilliC, Ulaş H. Psikiyatrikonsültasyonlarında deliryum. Demans Dergisi 2003;3:127-30.

26. Hosie A, Davidson PM, Agar M, Sanderson CR, Phillips J. Delirium prevalence, incidence, and implications for screening in specialist palliative care inpatient settings: a systematic review. Palliat Med 2013;27:486-98.

27. Ozen ME, Orum MH, Kalenderoglu A. The burden of schizophrenia on caregivers. Psychiatry Behav Sci 2018;8:105-10. 